\title{
納豆のにおいの一成分について \\ An Odorous Component of Natto, Fermented Soy-beans
}

著者等は枯草菌代謝産物の研究中, その培養液より昇華性物質を単離し, tetramethylpyrazine であることを 決定した ${ }^{1)}$.

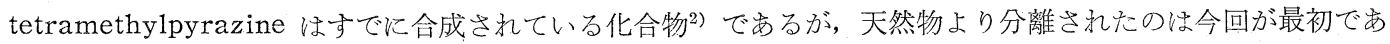
り, pyrazine 骨核を有する化合物としても, Baxter 等に上り Aspergillus flavus 上り分離された Aspergillic $\operatorname{acid}^{3)}$ そつぐものとして極めて興味深い化合物である。

tetramethylpyrazine は極めて強い年華性を有し，そのに扔いはある濃度では市販納豆に上く似ている・納豆 菌も枯草菌と同じく Bacillus 属に属し, 納豆のに扔いの中に tetramethylpyrazine が存在する可能性がある ので, 市販納豆より tetramethylpyrazine の単離を志し, その目的を達した.

すなわち市販納豆約 $1.8 \mathrm{~kg}$ を約 $5 \mathrm{~L}$ の水に懸濁させて布で汇別し, 沪液を濃縮する。气の留液に食塩を飽和 させてェーテルで抽出する。乾燥したェーテル溶液に適当量のピクリン酸を加え, エーテルを留去する. 析出し た picrate を少量のエーテルで洗浄しアアルコールで再結晶すれば $0.3 \mathrm{~g}$ の picrate 省得る.この picrate の IR スペクトルは tetramethylpyrazine picrate と微細構造采で完全に一致し, 納豆のに怙いの一成分として tetramethylpyrazine が存在することが推定された. Bacillus natto の純培養に招いても, 同一物質の分離が 期待できるので, 納豆菌の培養液より本物質相当量を得た後, その化学構造が tetramethylpyrazine であるこ とを確定する予定である.

$\begin{array}{ll}\text { Shizuoka College of Pharmacy, } & \text { 小菅 卓 夫 (Takuo Kosuge) } \\ \text { Oshika, Shizuoka } & \text { 神 谷弘子 (Hiroko Kamiya) } \\ \text { Shizuoka Factory of Yakult Co. } & \text { 足立太 平 (Tahei Adachi) }\end{array}$

October 24,1961

1) T. Kosuge, H. Kamiya : Nature (to be published.)

2) Demetre-Vcadesco : Bull. soc. chim. France [3] 6, 820.

3) R. A. Baxter, F.S. Spring: J. Chem. Soc. 1947, 1179. 